\title{
Correction to: Horizon Europe: Will new or old European Union take to the field?
}

\author{
Michele Rubbini ${ }^{1}$ (10)
}

Published online: 14 November 2019

(C) Swiss School of Public Health (SSPH+) 2019

\section{Correction to: International Journal of Public Health}

https://doi.org/10.1007/s00038-019-01296-z

Unfortunately, the given and family name of author "Michele Rubbini" was interchanged incorrectly in the original publication and the correct version is updated here. The original article has been corrected.

Publisher's Note Springer Nature remains neutral with regard to jurisdictional claims in published maps and institutional affiliations.

The original article can be found online at https:// doi.org/10.1007/s00038-019-01296-z.

Michele Rubbini rbb@unife.it

1 Department of Morphology, Surgery and Experimental Medicine, University of Ferrara, Ferrara, Italy 